\title{
Zakony - dziennikarze - komunikacja ze światem. Jak przerwać tabu o życiu w klasztorze?
}

Mgr red. Magdalena DrohomireckA

Uniwersytet Papieski Jana Pawła II w Krakowie

Jak przerwać tabu o życiu w klasztorze? Ileż osób zadaje sobie to pytanie? Pewnie niemal każdy, kto zakonnice i zakonników widuje tylko z daleka, na ulicy lub w kościele, a nie ma ich wśród znajomych, przyjaciół czy bliższej lub dalszej rodziny. Wydawałoby się, że bycie dziennikarzem ułatwia poznawanie świata, docieranie tam, gdzie „zwykły” człowiek nie ma wstępu. I rzeczywiście tak bywa. Ale niestety tylko „bywa”. Ponieważ, szczególnie w tym przypadku, trzeba mieć w sobie potrzebę dotarcia do prawdy, determinację do jej poznawania i wewnętrzną niechęć do ulegania stereotypom. To właśnie skłonność do dawania wiary stereotypowego myśleniu najczęściej pokazuje nam świat w krzywym zwierciadle. Jest narzędziem groźnej manipulacji, która ukazuje dziennikarzowi „jedynie słuszny” obraz świata, a ten, wykorzystując swój zawodowy dostęp do mediów, karmi półprawdami czytelników, słuchaczy i telewidzów. Mowa o ludziach i mediach nieprzychylnych Kościołowi, których jest niemało, a ich zasięg w docieraniu do społeczeństwa bywa niebezpiecznie duży. 
Przykładów takiego destruktywnego działania można podać wiele. Szukając w Internecie publikacji uchylających rąbka tajemnicy o życiu za klasztornymi murami, znalazłam wyłącznie historie o siostrach, które wyszły ze zgromadzeń $i$,wreszcie wolne" opowiadały o krzywdach, poniżeniu i cierpieniach, jakich miały doznać za klasztornymi murami. Intrygujący jest fakt, że najostrzej atakującymi Kościół są właśnie osoby, które zrezygnowały z wybranej przez siebie drogi zakonnej czy kapłańskiej. Są one, jeśli tylko wyrażają chęć, często zapraszane do udziału w różnych audycjach, których cel jest jeden: atak na Kościół, pod pretekstem r z ek o m e go przerwania tabu o życiu w klasztorze, ale w zupełnie odwrotnym znaczeniu niż w tytule niniejszej publikacji.

A zatem rola dziennikarza pragnącego uczciwie przybliżyć społeczeństwu codzienność za klasztornymi murami jest tym bardziej trudna i odpowiedzialna. Zacząć trzeba od poznania i zdobycia zaufania tych, o których codzienności będziemy opowiadać. To nie jest łatwe zadanie. Wśród osób, które poświęciły swoje życie Bogu, pojawia się podświadomy niepokój o to, czy można zaufać dziennikarzowi. Czy można opowiedzieć mu o sobie, swojej codzienności, wierząc, że myśli, które zamienią się w słowa, zostaną przekazane prawdziwie i bez podtekstów? Wydaje się, że ostatnie lata stanowią przełom w obdarzaniu się wzajemnym zaufaniem i otwartością, zarówno wśród zakonnic i zakonników, jak i wśród dziennikarzy.

Światowe Dni Młodzieży, które odbyły się w Krakowie w lipcu 2016 roku, znakomicie pokazały zrozumienie, a nawet jedność między tymi dwoma środowiskami, które - wy- 
dawałoby się - dzieli wszystko: postrzeganie świata, sposób życia, codzienność. Okazało się jednak, że odmienny wybór drogi życiowej nie dzieli, a wręcz chwilami łączy. Wpłynęło na to w owym czasie wiele czynników. Najpierw euforia oczekiwania na to wyjątkowe wydarzenie, jakim były Światowe Dni Młodzieży w Krakowie, potem euforia wspólnych duchowych przeżyć, ale także zabawy. Dziennikarze dowiedzieli się przede wszystkim, że osoby żyjące za klasztornym murem wcale nie są oderwane od rzeczywistości i niezaznajomione ze współczesnym światem. Bywają znakomitymi organizatorami, ludźmi o wszechstronnej wiedzy, fachowcami w swoich dziedzinach. Są osobami rozśpiewanymi, z poczuciem humoru, chętnymi do wspólnej zabawy. Obserwowałam z ciekawością widoczną wtedy zmianę w nastawieniu młodych reporterów Telewizji Kraków, relacjonujących wydarzenia ze Światowych Dni Młodzieży, do przedstawicieli zakonnego świata. Bezpośredni kontakt na ulicach miasta, nagrywanie ich wypowiedzi, a także zwyczajne rozmowy przerwały tabu o życiu w zakonach. Zdumienie dziennikarzy (niektórzy po raz pierwszy zetknęli się w tak bezpośredni sposób zludźmi Kościoła) było ogromne. Zamknięci w obowiązujących stereotypach, nie próbując wcześniej dowiedzieć się czegoś więcej, byli pozytywnie zaskoczeni.

Oprócz kluczowej roli dziennikarzy w kwestii wysyłania społeczeństwu przekazu o otaczającym nas świecie i jego zjawiskach bardzo ważne jest, aby także zakonnice i zakonnicy wyszli naprzeciw tej konieczności. Z pełną odpowiedzialnością stawiam tezę, że to właśnie konieczność. Brak wiedzy o życiu w klasztorach, a tym samym łatwość ulegania 
manipulacji, jakiej poddawane są osoby świeckie, mogą być zabójcze dla wiedzy o zakonnym świecie. Obraz malowany nie tylko w tabloidach, ale także w mediach uznawanych za opiniotwórcze pokazuje często w krzywym zwierciadle nie tylko codzienność klasztornego życia, ale przede wszystkim podważa rację wyboru takiej drogi życiowej, deprecjonując ją i wskazując na rzekome patologie w domach zakonnych.

Dlatego tak bardzo istotna jest tytułowa współzależność zakonów, dziennikarzy i ich komunikacji ze światem. To wręcz podstawa właściwego przekazu. To warunek sine qua non zatrzymania zjawiska manipulacji i półprawd. Dlatego też świat zakonny musi otwierać się na kontakty z dziennikarzami, a w konsekwencji - ze społeczeństwem. Opowiadać o swoim życiu, pokazywać własną aktywność w świeckim świecie: misje, działalność wychowawczą, opiekuńczą, edukacyjną czy naukową. Pokazywać także, że nowoczesne, często zabawne sposoby komunikacji są znane siostrom i braciom. Znakomitym przykładem może być spot nagrany przez zakonnice na siłowni, zachęcający do wpłat na konieczny remont domu dziecka, który prowadzą w Siennicy na Mazowszu. „Strzał” był tak celny, że udało im się zabrać niemal całą potrzebną kwotę. Materiał znalazł się w ogólnopolskim programie informacyjnym. To dowód, że tego typu sposób komunikacji ukazuje kobiety, które znalazły powołanie w służbie Bogu, jako osoby obdarzone zarówno poczuciem humoru, jak i dystansem do siebie. Widać, że znają one nowoczesne i modne, a tym samym trafiające na podatny grunt, sposoby komunikacji i przekazu. A to przecież bardzo ważny przekaz. Dotyczy nie tylko tej jednej szczególnej i szlachetnej idei, ale przede wszystkim jest sy- 
gnałem dla młodych dziewcząt mówiącym, czym zajmują się siostry i jak żyją. To niepodważalna wartość w czasie, gdy liczba powołań nie jest zbyt wysoka, czego przyczyną może być między innymi wskazany już przekaz o życiu zakonnym, jaki dociera do społeczeństwa.

Brak właściwej komunikacji to brak wiedzy. Zarówno o życiu w klasztornych murach, jak i o ciężkiej pracy zakonnic i zakonników, jakże bliskiej codziennym ludzkim problemom. Dobrym przykładem może być Zgromadzenie Córek Bożej Miłości obchodzące w 2018 roku 150-lecie swego istnienia. Gdy Franciszka Lechner założyła półtora wieku temu w Wiedniu owo zgromadzenie, powołaniem sióstr była - i jest do tej pory - opieka społeczna, zjawisko w owych czasach niespotykane i niesłychanie nowoczesne. Zakonnice zajmowały się pośrednictwem pracy, udzielaniem schronienia dziewczętom przybywającym ze wsi do miasta, dbały o ich moralność i wykształcenie. Siostry działają obecnie na całym świecie. W Krakowie prowadzą przedszkole. Kto o tym wie? Być może dzięki obchodom rocznicowym i dzięki ich obecności w mediach coraz więcej osób pozna ich działalność. Szerzenie takich właśnie informacji jest powinnością dziennikarską. Siostry pracujące z młodymi kobietami, często w trudnych, kryzysowych sytuacjach, nie są oderwane od życia, przeciwnie - stykają się bardzo często z jego ciemnymi stronami.

O tym, że życie zakonne nie wyklucza rozwijania swoich talentów, świadczy słynny już i szeroko komentowany występ w The Voice of Italy urszulanki, siostry Cristiny Scuccii. „Jako dobrzy szafarze różnorakiej łaski Bożej służcie sobie nawzajem tym darem, jaki każdy otrzymał" - tym zdaniem 
z Pierwszego Listu św. Piotra kard. Gianfranco Ravasi odpowiedział na występ siostry Cristiny. Taki przekaz wychodzi naprzeciw nieprzychylnym komentarzom i publikacjom o życiu zakonnym, przekazom opartym na rzekomo tragicznych przeżyciach sióstr, które opuściły klasztor i najczęściej, jak czytamy, ze strachu wypowiadają się anonimowo. Gdy świat dowiedział się, że to właśnie udział w muzycznych konkursach zbliżył siostrę Cristinę do Boga, a urszulanki same skierowały ją na naukę śpiewu, zostało przełamane kolejne tabu. Tę informację podchwycili dziennikarze, pokazując odbiorcom inne niż zwykle oblicze zakonnego życia.

I to jest właśnie zadaniem mediów. Przekaz unikający stereotypów, szukający prawdy, dociekający wiedzy i komunikujący świecki świat z życiem zakonnym. Jak przerwać tabu? Unikając sensacji, pisząc i mówiąc publicznie prawdę. 